\title{
RESPONSES AND EXPECTATIONS REGARDING MUNICIPALITY DECLARATION: A CASE OF BAGLUNG MUNICIPALITY
}

\author{
Kishor Bajra Bajracharya \\ Reader \\ Department of Geography Education \\ Tribhuvan University, Kirtipur
}

\begin{abstract}
The process of declaration of municipality is taking place in Nepal at times but not in the regular way and with given regulations. Transformation into a municipality has been regarded as a matter of great pride and reputation in many cases, so was the case of Baglung as well. The proclamation of municipality does not possess any probation period to make any necessary modification. When the people have to face taxation and many other economic liabilities after having the designation of municipality, a sort of uneasiness and inconvenience grips them. Nothing was known in this regard in many cases and Baglung is not an exception.
\end{abstract}

Key words: Municipality, settlement, declaration, ethnic groups, Lichhavi, Malla, Rana rulers and Skandapuran.

\section{Introduction}

Historical monuments and evidences of varied forms indicate that the application of the term 'town', in Nepal, dates from the Lichhavi period, but its legal status has not yet been clarified. Reports by foreign travelers refer to the existence of large settlements and some of these make comments on the characteristics of the larger settlements. These include most of the present best-known municipalities i.e. Kathmandu, Banepa, Bhaktapur etc. The first modern census of Nepal - 2052/54 B.S., was associated with the first authorized proclamation of municipality in Nepal, but contains no comment on the definition and significance involved.

During the period of the three decade long Panchayat regime, the municipality was referred to as a 'Town Panchayat', abiding by the laws of the period. After the restoration of multi-party system in 2046 B.S., the term 'municipality' once again came into practice along with the provision classification eg into Metropolitan, SubMetropolitan and Municipality, ), on the basis of the particular elements in accordance with the specific range of value.

Municipality declaration has taken place at various times but has generally lacked fixed timing. Procedures as stated by the law are also not being followed in strict sense, in some cases. Manipulation of the political forces has been identified as being very strong in the process of municipality declaration. The demand of people for municipality declaration has also been found to be very strong in a number of cases.

Present paper is presented with a view to eliciting the responses and raising the expectations of those most directly concerned on the basis of an examination of the case of Baglung Municipality. The discussion found in this paper is based on a field survey undertaken in 2002 A.D., using the RRA approach and method. First, however, a brief account is provided on the physical, historical and socioeconomical context of Baglung municipality.

\section{Physical Setting}

The merging of three VDCs namely Kalika, Mulpani and Lahare Pipal gave rise to the present municipality of Baglung, covering an area of 18.35 square kilometers. Geologically, it occupies the central higher mountain zone. Geographically, this municipality is situated on the confluence of Krishna Gandaki river to the north and Kanthe Khola to the south, by accommodating the river side, the flat east-west stretching plateau bounded by the rocky cliffs from three sides and the high mountain range to the west.

Baglung Bazaar itself is located on the plateau, which widens from west to east, along with the step like broad stony terraces to the eastern and south-eastern edges. The geographical location of Baglung Municipality is on the northern eastern edge. The municipality is bounded by Parbat District in the east, the Baglung District 
VDCS of Tityang, and Singana in the south and Palakot in the west, with Myagdi District to the north.

East facing, the relief features of Baglung Municipality show a high gradient from east to west, starting from the bank of the Kali Gandaki river. Red clay soil is found dominant in most of the areas. The climate is highly affected by altitude, especially to the west and northern parts and the plateau and river side areas enjoy sub-tropical nature having hot and rainy summer and cold winter. Large parts of this municipality are found nearly $1000 \mathrm{~m}$ above sea level. River side areas, rocky cliff areas and steep terrain are endowed with natural vegetation because of being untouched by human encroachment. Old Baglung Bazaar is now virtually without natural vegetation.

\section{Historical Settings}

Baglung, the name of the municipality as well as the district, is derived from the old Baglung bazaar. Baglung bazaar is the oldest and currently the largest settlement of Dhaulagiri zone. It is also the district and zonal headquarters. Old Baglung bazaar remains as the core of the present Baglung municipality.

Different opinions are found regarding the origin of the word 'Baglung'. Most of the researchers have accepted the fact that its origin dates back to about 5000 years ago. The legend says that the area was once crowded with number of tigers, where the strong men of Magar community usually came to kill tigers; as such the place was called as 'Baghra Lunya' or 'Byaghralun' in Sanskrit language. The term 'Bagha' denotes 'tiger' in the Khas language. 'Lung' denotes group. The area having been wandered by groups of tigers, was thus called 'Baglung'.

On the other hand, there is a place called as 'Bauling' in Dhikichaur of Gairigaon, Mulpani VDC, ward no. 1. Perhaps, the word 'Baglung' is derived from the term 'Bauling'. In Magar language 'Lung' means 'bed without legs'. However, in the Rai language, the term 'Baglung' denotes 'a stone like a pig'. These kind of stones are found everywhere in Baglung.
Finally, it could be that Tibetans, who visited the area in earlier times, called it as 'Baglung' in their own language and this name later was accepted by the locals. Supporting this fact that 'Bag' refers to an area with some elevated portion and 'Lung' refers to a level plain area in Tibetan language.

It may be relevant that the name of many other places in the area somewhat resemble that of 'Baglung' - Burtibang, Nangliwang, Bowang and Jhorwang.

According to the 'Skandhapuran', the place has a highly religious significance. It is where the wife of Lord Shiva, Parvati, had taken the incarnation as 'Bhagwati' who had been taken care by the group of tigers. As such, the area has got name as 'Baglung'. On the spot where Parvati undertook her meditation, a temple was built during 1591-1593 B.S by Narayan Malla to 'Mahasaraswati' 'Mahalaxmi' and 'Mahakali' and received in token of dowry from the then king of Palpa 'Mani Mukunda Sen'. This is mentioned in a historical inscription.

Old people certainly say that the area was under the rule of Thakuri rulers in the earlier days, and still today some lands are owned by Thakuri groups.

The renowned historical settlement of old Baglung was annexed into 'greater Nepal' by Amar Singh Thapa under the leadership of Bahadur Shah, during the rule of king Rana Bahadur Shah.

\section{Socio-Economic Settings}

The presence of very favorable geographical condition and the possession of strategic location made old Baglung as an important place for trading activity, administrative work, social and cultural characteristics of the surroundings. The history of medieval and modern period has witnessed a number of evidences in this regard. The ancient epics have also noticed that Baglung has earned a great importance on cultural, religious, economic and administrative aspects. The importance has been increased a lot right after the recovery of democracy.

Baglung Municipality comprises of various ethnic groups, including Newars, Magars, 
Thakuris, Chhetris and others. As a result, it has long been characterized by diversified cultural characteristics. Besides, there are many historical, religious and cultural monuments, holy places, especially around the old Baglung bazaar.

The completion of the Pokhara-Baglung highway $(72 \mathrm{~km})$ in 2051 B.S. has strengthened its social and economic condition by linking it to the national road network. Identical economic activities of Baglung, like Nepali paper manufacturing, artistic wooden products and many more have been well supported by the available infrastructures. The development infrastructures are particularly concentrated in and around the old Baglung bazaar.

The presence of infrastructures has contributed a lot to boost up the economic activities. Lying on the way of the famous Annapurna trekking, many tourist oriented economic activities have also been flourishing especially in the present context.

\section{Administrative Settings}

Baglung Municipality was recognized as an authentic municipality in 2054 B.S. (1997 A.D.). It was the first formal municipality of the Dhaulagiri zone as a whole. Altogether, there are eleven wards at present.

Old Baglung bazaar is accommodated within the wards 1 and 2. Most of the official houses are also located in and around the old Baglung Bazaar.

\section{Demographic Settings}

The demographic characteristics of the respondents as received from the survey are presented in Table 1. According to the table 1, male respondents (88\%) remain dominant. The age group 36-50 years also predominates the rest age groups. Brahmins constitute the largest group (44\%) as against Newars (32\%), Chhetris $(20 \%)$ and others (4\%). The largest number of respondents $(52 \%)$ is found in higher education followed by high school level (40\%) and literate

Table 1: Demographic Characteristics of the Respondents

\begin{tabular}{|l|c|c|}
\hline Characteristics & Number & Percentage \\
\hline Sex: Male & 22 & 88 \\
\hline Sex: Female & 3 & 12 \\
\hline Age: Below 35 years & 7 & 28 \\
\hline Age: 36 - 50 years & 11 & 44 \\
\hline Age: 51 and above & 7 & 28 \\
\hline Ethnicity: Brahman & 11 & 44 \\
\hline Ethnicity: Chhetri & 5 & 20 \\
\hline Ethnicity: Newar & 8 & 32 \\
\hline Ethnicity: Others & 1 & 4 \\
\hline Education: Literate & 2 & 8 \\
\hline Education: High School & 10 & 40 \\
\hline Education: Higher Education & 13 & 52 \\
\hline Religion: Hindu & 22 & 88 \\
\hline Religion: Buddhist & 2 & 8 \\
\hline Religion: NA & 1 & 4 \\
\hline Marital Status: Married & 22 & 88 \\
\hline Marital Status: Unmarried & 3 & 12 \\
\hline Family Members: Up to 3 & 1 & 4 \\
\hline Family Members: Up to 5 & 17 & 68 \\
\hline Family Members: More than 5 & 7 & 28 \\
\hline Dwellers: Local & 22 & 88 \\
\hline Dwellers: Outsider & 3 & 12 \\
\hline Eco. Active F. Members: NA & 2 & 8 \\
\hline Eco. Active F. Members: Up to 2 & 9 & 36 \\
\hline Eco. Active F. Members: Up to 4 & 4 & 16 \\
\hline Eco. Active F. Members: More than 4 & & 40 \\
\hline Sourc: Fiel Surve 2002 & \\
\hline
\end{tabular}


( $8 \%$ ). The followers of Hindu religion are by far the majority $(88 \%)$, followed by Buddhist $(8 \%)$ and others (4\%). Married respondents $(88 \%)$ are found in clear numerical predominance as against unmarried respondents (12\%). Families having up to 5 members (68\%), outnumber those with more than 5 family members $(28 \%)$, and 'others' (4\%). Local residents (88\%) comprise the dominant group. Among families with economically active family members, those with more than five economically active members comprised the largest group (40\%).

\section{Expectations}

A massive number of respondents (96\%) agreed that the declaration of municipality is a good decision because it was a matter of pride for the whole Dhaulagiri zone.

The expectations of the respondents regarding the consequences of declaration of municipality are displayed in Table 2.

As Table 2 shows, there are 13 expectations identified by the respondents, ranked according to priority. Drinking water with a regular supply was a prime expectation of almost all and affordable communication $(72 \%)$. The regular maintenance of all facilities $(64 \%)$, good and affordable health facilities (60\%), healthy administration $(60 \%)$, contribution of government $(60 \%)$ and employment opportunities $(56 \%)$ are the rest of the expectations of the respondents.

The above mentioned data directly reveal that the respondents had high expectations of the consequences of the declaration of Baglung Municipality. Most of the expectations include positive changes in infrastructures, social facilities and economic opportunities. Respondents' expectations indicate a hope that the new status will bring many positive changes to promote the socio-economic development of the municipality. Indirectly, they also indicate various problems.

\section{Participation}

During the process of municipality declaration, many people were involved directly and indirectly. Their participation is shown below, in Table 3, which identifies their occupation and/or profession.

Table 2: Expectations of the Respondents on the Declaration of Municipality

\begin{tabular}{|l|c|c|}
\hline Expectations & Number & Percentage \\
\hline A good regular supply of drinking water & 24 & 96 \\
\hline A good and durable vehicle road & 23 & 92 \\
\hline A regular supply of electricity & 23 & 92 \\
\hline Development of other infrastructures & 20 & 80 \\
\hline Regular disposal of waste & 19 & 76 \\
\hline Good sanitation system & 19 & 76 \\
\hline Availability of good and affordable education & 18 & 72 \\
\hline Availability of good and affordable communication & 18 & 72 \\
\hline Good and regular maintenance of all activities & 16 & 64 \\
\hline Availability of good and affordable health facilities & 15 & 60 \\
\hline Fair and healthy administration & 15 & 60 \\
\hline Maximum contribution from government & 15 & 60 \\
\hline Availability of enough employment opportunities & 14 & 56 \\
\hline
\end{tabular}

Source: Field Survey, 2058 B.S.

respondents (96\%), being followed by the expectation of motorable roads (92\%), a regular supply of electricity (92\%), the development of other infrastructures $(80 \%)$, the regular disposal of waste $(76 \%)$, a good sanitation system $(76 \%)$, a good and affordable education (72\%) and good
Table 3 shows that with the exception of teachers, the vast majority $(80 \%)$ of other professional respondents have participated in the process of municipality declaration. Overall, majority of the respondents took part in the process. 


\section{Improvements}

Responses as provided by the respondents on the issue of improvements after the establishment of Baglung Municipality have come of about 84 percent in the acceptance of

\section{Ward and VDC Boundaries}

The present area of Baglung Municipality was also the subject of enquiry and the responses received are presented in Table 5. It is clear that, apart from politicians $(40 \%)$, all other

Table 3: Respondents' Participation in Municipality Declaration Participation

\begin{tabular}{|l|l|l|l|l|}
\hline Respondents & Yes & Percentage & No & Percentage \\
\hline Politicians & 4 & 80 & 1 & 20 \\
\hline Social Workers & 4 & 80 & 1 & 20 \\
\hline Traders & 4 & 80 & 1 & 20 \\
\hline Teachers & 2 & 40 & 3 & 60 \\
\hline Officials & 4 & 80 & 1 & 20 \\
\hline Total & 18 & 72 & 7 & 28 \\
\hline
\end{tabular}

Source: Field Survey, 2058 B.S.

being in positive side. The improvements that were spelled out by the respondents included the following activities: professional respondents $(80-100 \%)$ strongly support the present ward and VDC boundaries.

Table 4: Position of Benefit Groups

\begin{tabular}{|l|c|c|}
\hline Respondents & Number & Percentage \\
\hline Traders & 12 & 48 \\
\hline Public & 8 & 32 \\
\hline Politicians & 5 & 20 \\
\hline
\end{tabular}

Source: Field Survey, 2058 B.S.

- The construction of roads within municipality.

- The establishment of sewage at many places.

- The disposal of wastages from inner market areas.

- The establishments of parks, streetelectricity lamps.

- The increasing of telephone lines.

- The regular transportation system.

- The regular cleanliness of inner market areas.

Responses of respondents regarding the enjoyment of the given improvements are presented on the basis of profession in Table 4.

The facts as shown by table 4 are crystal clear. Traders (48 percent) have been able to entertain the maximum benefit from the provided improvements by comparison with other categories. The declaration of municipality status has had some good efforts and some professional respondents have also succeeded in acquiring significant advantages.

\section{Performances}

Efforts that have been done by the Baglung Municipality are being asked with the respondents. The listing of positive and negative works as collected from the respondents is given below in Table 6 . The outcome of performance has been well accepted by a majority of the respondents. Problems of party based activities are seen as the most troubling ones.

\section{Problems}

Table 6 shows that most of the perceived problems are connected with the economic aspect, which does not emerge at the VDC level. Most problems are town oriented ones. Perhaps, the respondents had never thought or imagined about these problem before the declaration of municipality. The list of problems faced by the respondents themselves after the declaration of municipality is shown below in Table 7 in accordance with the priority given to these problems by the respondents themselves. 
Table 5: Respondent's Response on its Boundary Lines

\begin{tabular}{|l|c|c|c|c|}
\hline \multirow{2}{*}{ Respondents } & \multicolumn{4}{|c|}{ Responses } \\
\cline { 2 - 5 } & Yes & Percentage & No & Percentage \\
\hline Traders & 5 & 100 & - & - \\
\hline Teachers & 4 & 80 & 1 & 20 \\
\hline Social Workers & 4 & 80 & 1 & 20 \\
\hline Officials & 4 & 80 & 1 & 20 \\
\hline Politicians & 2 & 40 & 3 & 60 \\
\hline Total & 19 & 76 & 6 & 24 \\
\hline
\end{tabular}

Source: Field Survey, 2058 B.S.

\section{Remedies}

The remedies suggested by the respondents themselves, in order to overcome the problems mentioned are listed in Table 8, on the basis of priority as defined by the respondents. more sensitive and delicate than others. The rest of the suggested remedies are fairly predictable and tend to link straight to the area of development activities, where the target is aimed

Table 6: Performance of Municipality Works

\begin{tabular}{|l|c|c|l|c|c|}
\hline \multirow{2}{*}{ Positive } & \multicolumn{2}{|c|}{ Respondents } & Negative & \multicolumn{2}{|c|}{ Respondents } \\
\cline { 2 - 4 } \cline { 5 - 6 } & Number & $\%$ & & Number & $\%$ \\
\hline Construction of sewage & 20 & 80 & Party based politics & 8 & 32 \\
\hline Construction of road & 20 & 80 & Bias of politicians & 6 & 24 \\
\hline Construction of parks & 18 & 72 & Late working & 5 & 20 \\
\hline Removal of waste & 18 & 72 & Time consuming & 5 & 20 \\
\hline Management of street lamps & 16 & 64 & & & \\
\hline Supply of drinking water & 16 & 64 & & & \\
\hline
\end{tabular}

Source: Field Survey, 2058 B.S.

The responses listed in Table 8 suggest that tax reduction is seen as a priority together with 'easy, fast and cheap procedure for housing construction permission' by the majority (96\%) of the respondents. This is an immediate to ease out and facilitate the traditional difficulties and hindrances.

All above, the data collected explicitly demonstrate that the local respondents have a

Table 7 : Problems of Respondents

\begin{tabular}{|l|c|c|}
\hline \multirow{2}{*}{ Problems } & \multicolumn{2}{|c|}{ Respondents } \\
\cline { 2 - 3 } & Number & Percentage \\
\hline Increasing of tax & 22 & 88 \\
\hline Permission for housing construction & 21 & 84 \\
\hline Time consuming administrative procedure & 20 & 80 \\
\hline Insufficient sewage system & 19 & 76 \\
\hline Irregular maintenance of roads & 18 & 72 \\
\hline Increase in rental value & 16 & 64 \\
\hline Shortage of land & 14 & 56 \\
\hline Vehicle tax & 10 & 40 \\
\hline Lack of bus park & 10 & 40 \\
\hline Absence of co-ordination & 8 & 32 \\
\hline
\end{tabular}

Source: Field Survey, 2058 B.S.

response to the declaration and directly touches on an economic aspect. People felt these matters to be very important yet recognised they were great urge to curb what they see as problems and manifest a great hope and willingness to keep Baglung Municipality away from possible hindrances to economic and social development. 
Table 8: Remedies as Quoted by the Respondents

\begin{tabular}{|l|c|c|}
\hline \multirow{2}{*}{ Remedies } & \multicolumn{2}{|c|}{ Respondents } \\
\cline { 2 - 3 } & Number & Percentage \\
\hline Reduce tax to the possible extent & 24 & 96 \\
\hline $\begin{array}{l}\text { Make easy, fast and cheap procedure for } \\
\text { housing construction permission }\end{array}$ & 24 & 96 \\
\hline Take care of major infrastructure facilities & 22 & 88 \\
\hline Keep administration smooth and fast & 22 & 88 \\
\hline Disseminate the information to the people & 21 & 84 \\
\hline $\begin{array}{l}\text { Administer the co-ordination among } \\
\text { agencies }\end{array}$ & 20 & 80 \\
\hline Control on political bias & 18 & 72 \\
\hline Conduct regular interaction with the people & 18 & 72 \\
\hline Seek another source of earning, making & 17 & 68 \\
\hline Minimum pressure to the people & 15 & 60 \\
\hline Manage a suitable site for bus park & 14 & 56 \\
\hline Promote and encourage public participation & 12 & 48 \\
\hline Invite and share with NGOs and INGOs & 10 & 32 \\
\hline Establish a good relationship with all & 8 & \\
\hline
\end{tabular}

Source: Field Survey, 2058 B.S.

Remedies include a variety of characteristics. Application of the suggested remedies would undoubtedly be a major enterprise, requiring the consideration of many things, and there is clearly a felt need that this will take time and effort.

\section{Conclusion}

The declaration of Baglung Municipality was expected and demanded one. The acceptance of the declaration was natural. The feeling was there as a matter of pride and reputation for the whole Dhaulagiri Zone, because of being declared as the first one. Besides, there have been lots of expectations on its declaration.
Responses as shown by the respondents point out that Baglung Municipality has been providing a satisfactory performance so far in a short span of time, though the different level of advantages have been noticed among the varied professional respondents. Raised problems by the respondents seem critical and the burden of tax and other economic liabilities has made them inconvenient and uncomfortable and other problems are objective in nature. Remedies as forwarded by respondents are pinpointed and the priority as undertaken to list them seems to be based on more particularly on economic aspect.

\section{References}

Baglung Municipality (2098). Baglung : Nagar Darpan.

CBS (2002). Statistical Pocket Book. Kathmandu: Central Bureau of Statistics.

CBS (2002). Population Census 2001. Kathmandu: Central Bureau of Statistics.

Gurung, H.B. (1980). Vignettes of Nepal. Kathmandu: Sajha Prakashan.

HMG, Baglung District Office (2000). Krishi Bikas Karyakaram 2000 (2956/57 B.S.). Baglung: District Office.

Sharma, B.C. (1994). Nepalko Aitihasik Ruprekha. Banaras: Krishna Kumari Devi.

Shrestha, G. L. "Sero Phero Mero". Baglung : Dhaulashree Cottage, Kalimati Height. 